\title{
Data report: clues about carbon cycling in methane- bearing sediments using stable isotopes of the dissolved inorganic carbon, IODP Expedition $311^{1}$
}

\author{
M.E. Torres ${ }^{2}$ and M. Kastner ${ }^{2}$
}

\section{Chapter contents}

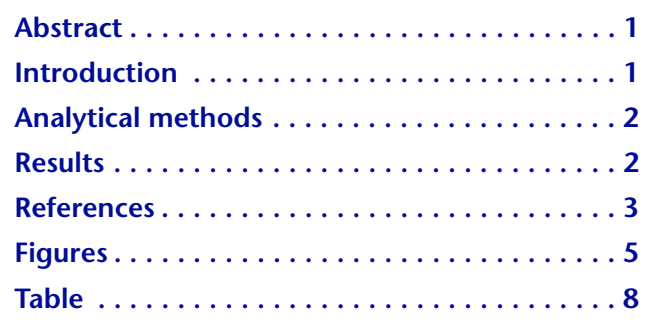

'Torres, M.E., and Kastner, M., 2009. Data report: clues about carbon cycling in methane-bearing sediments using stable isotopes of the dissolved inorganic carbon, IODP Expedition 311. In Riedel, M., Collett, T.S., Malone, M.J., and the Expedition 311 Scientists, Proc. IODP, 311: Washington, DC (Integrated Ocean Drilling Program Management International, Inc.).

doi:10.2204/iodp.proc.311.206.2009

${ }^{2} 104$ COAS Administration Building, Oregon State University, Corvallis OR 97331-5503, USA.

Correspondence author:

mtorres@coas.oregonstate.edu

\section{Abstract}

The isotopic characterization of carbon in the dissolved inorganic carbon (DIC) pool is fundamental for a wide array of scientific studies directly related to gas hydrate research. Here we present the DIC data from pore fluid samples recovered from the northern Cascadia accretionary margin during Integrated Ocean Drilling Program (IODP) Expedition 311. Comparison of these results with data obtained from offshore central Cascadia during Ocean Drilling Program Leg 204 provides clues on carbon cycling processes that control methane inventories and fluxes.

Microbial methane production preferentially incorporates the light carbon isotope. As sediment ages, more of the original $\mathrm{CO}_{2}$ is converted to methane, leaving behind an isotopically heavier residual DIC. This DIC is progressively enriched in ${ }^{13} \mathrm{C}$ below 200 meters below seafloor with increasing distance from the deformation front.

In the shallower sections, minima in downcore $\delta^{13} \mathrm{C}_{\mathrm{DIC}}$ profiles coincide with the sulfate-methane transition (SMT) zone. Here the $\delta^{13} \mathrm{C}_{\mathrm{DIC}}$ values provide information on the metabolic pathways that consume sulfate and reveal that anaerobic oxidation of methane $(\mathrm{AOM})$ is not the dominant reaction at all sites drilled. There appears to be no simple correlation between the extent of AOM, depth of the SMT, and thickness of the gas hydrate occurrence zone along the transect drilled in northern Cascadia.

\section{Introduction}

Drilling on northern Cascadia was aimed at understanding the biogeochemical factors controlling the distribution and concentration of gas hydrates in an accretionary margin setting. To constrain the distribution and concentration of gas hydrate in this region, a transect of four sites (Sites U1325, U1326, U1327, and U1329) was drilled during Integrated Ocean Drilling Program (IODP) Expedition 311 (Fig. F1) (see the "Expedition 311 summary" chapter). A fifth site (Site U1328) was drilled south of the transect to target a cold vent with active fluid and gas flow where gas hydrate occurs near the seafloor. The four transect sites encompass the earliest gas hydrate occurrence on the westernmost accreted ridge (Site U1326) and extends to the eastward limit of gas hydrate occurrence (Site U1329). These sites complement previous drilling in central Cascadia during Ocean Drilling Program 
(ODP) Leg 204 (Fig. F1) (Tréhu et al., 2006). Several of the objectives in Expedition 311 and Leg 204 address fundamental questions pertaining to the carbon cycle and fluid transport in this accretionary margin, as these processes play fundamental roles in unraveling the source and flux of hydrocarbons to the gas hydrate stability zone (GHSZ). The isotopic characterization of the dissolved inorganic carbon (DIC) pool is critical to address these objectives, which include establishing carbon sources and metabolic paths for organic carbon decomposition, as well as allowing for reconstruction of the history of the development of this hydrate-bearing province based on analyses of carbonate deposits.

\section{Analytical methods}

The isotopic composition of DIC was measured in pore fluid subsamples that had been filtered through disposable $0.45 \mu \mathrm{m}$ Gelman polysulfone filters, preserved with $\mathrm{HgCl}_{2}$, and flame sealed in glass vials immediately after collection.

Samples from Sites U1325, U1326, and U1329 were analyzed at Oregon State University using a GasBench II automated sampler interfaced to a gas source stable isotope mass spectrometer as described in Torres et al. (2005). The sample headspace is flushed automatically with helium to reduce residual air. Acid $\left(100 \mu \mathrm{L}\right.$ of $\left.43 \% \mathrm{H}_{3} \mathrm{PO}_{4}\right)$ is then injected with a gas-tight syringe and the samples are allowed to evolve DIC as $\mathrm{CO}_{2}$ gas into the headspace. After an equilibration period of $\sim 12 \mathrm{~h}$, the headspace gases are flushed with a helium stream, which passes through a sample loop of selected volume $(50,100$, or $250 \mu \mathrm{L}$ ). The sample loop is charged with gas, and a known volume of sample is then transferred to a second helium stream that flows through a gas chromatography column (to separate $\mathrm{CO}_{2}$ from other gas compounds) and a porous membrane trap (to remove water). The dry sample stream is transferred to a Finnigan DELTAplusXL mass spectrometer, which integrates the relevant isotope masses $(\mathrm{m} / \mathrm{z}=44,45$, and 46) as the $\mathrm{CO}_{2}$ peak enters the source. The sample volumes used for these pore fluid samples (with alkalinity values ranging from seawater values to concentrations $>100 \mathrm{meq} / \mathrm{L}$ ) ranged from 30 to $50 \mu \mathrm{L}$. This low volume requirement allowed for duplicate measurements in selected samples to ascertain data precision. Based on multiple standard measurements, the overall precision of this technique is conservatively estimated to be better than $\pm 0.15 \%$ o (Torres et al., 2005). Standardization is provided by tank $\mathrm{CO}_{2}$ (referenced to an array of international standards), and analyses are monitored against a stock solution of reagent $\mathrm{NaHCO}_{3}$. The precision of the $\delta^{13} \mathrm{C}$ measurements based on replicate analyses of a $\mathrm{NaHCO}_{3}$ stock solution over a 7 week period is $\pm 0.07 \%$.

Pore fluid samples from Sites U1327 and U1328 were analyzed for $\delta^{13} C_{D I C}$ at Scripps Institute of Oceanography. Samples $(2-3 \mathrm{~mL})$ were treated with phosphoric acid, and after headspace equilibration, the isotopic ratios were measured using a Thermo-Finnigan Delta $\mathrm{XP}$ Plus stable isotope ratio mass spectrometer. The average precision of the analyses, determined from multiple determinations of National Bureau of Standards (NBS) and in-house standards, is 1.8\% ( $0.1 \%$ of seawater).

\section{Results}

A total of 160 pore fluid samples were analyzed for $\delta^{13} \mathrm{C}_{\text {DIC }}$; isotopic data are listed in Table T1. These data provide insights into two major issues involving carbon metabolic pathways and methane inventories: methanogenesis and methane oxidation. The methane source for the majority of gas hydrates recovered from northern Cascadia is known to have a biogenic origin (Whiticar et al., 1995; Claypool et al., 2006; Pohlman et al., 2006); less known, however, are the rates of methane generation and consumption that may be addressed with these results. These rates are key parameters in numerical models involving gas hydrate dynamics (generation, consumption, and recharge of the reservoir). Pore fluid samples recovered from $\sim 100$ to 200 meters below seafloor (mbsf) along the transect of sites drilled in the Cascadia margin during Expedition 311 are compared with similar samples recovered during ODP Legs 146 and 204. The isotopic composition of DIC pool at these sites shows a distinct and progressive enrichment in the $\delta^{13} \mathrm{C}$ of the residual dissolved $\mathrm{CO}_{2}$ from a reference site drilled west of the accretionary toe (Site $\left.888, \delta^{13} \mathrm{C}_{\mathrm{DIC}}=-5 \%\right)$ to Site U1329 $\left(\delta^{13} \mathrm{C}_{\mathrm{DIC}}=\right.$ $+32 \%$ ) drilled closest to the shore $(65 \mathrm{~km})$ at the eastern limit of gas hydrate occurrence in the margin (Fig. F2). The organic carbon diagenesis leading to methane accumulation began at $\sim 100 \mathrm{ka}$ when these sediments were deposited on the incoming plate. The progressively heavier $\delta^{13} \mathrm{C}$ values of the DIC reflect the preferential consumption of ${ }^{12} \mathrm{C}$ by methanogens acting on the residual $\mathrm{CO}_{2}$. Modeling efforts are under way to generate estimates of the methanogenesis rates from the progressive ${ }^{13} \mathrm{C}$ increases of the residual DIC. Preliminary results (Torres et al., 2007) suggest a good agreement between these estimates and those based on geochemical modeling (Claypool et al., 2006) and microbial culture (Colwell et al., 2008) studies. 
Some of this microbially produced methane is incorporated into gas hydrate and some is consumed by the coupled microbial reaction of anaerobic oxidation of methane (AOM) and sulfate reduction at the sulfate-methane transition (SMT) zone. Because biogenic methane is strongly depleted in ${ }^{13} \mathrm{C}\left(\delta^{13} \mathrm{C}_{\mathrm{CH} 4}=\right.$ $-85 \%$ o to $-65 \%$ ) (Whiticar et al., 1995; Claypool et al., 2006; Pohlman et al., 2006), the bicarbonate produced by AOM also has significantly more negative carbon isotopes than bicarbonate generated by decomposition of organic carbon. Samples recovered from the flanks of Hydrate Ridge (Sites 1244, 1245, and 1246) during Leg 204 clearly indicate that AOM does not play a significant role in sulfate consumption at these sites (Torres and Rugh, 2006), which is consistent with geochemical models (Claypool et al., 2006). Only at sites where active fluid seepage led to gas hydrate breaching at the seafloor (Sites 1248, 1249, and 1250) was there evidence of AOM. Similarly at Site U1328, where active methane seepage results in massive near-surface gas hydrate accumulation, there is clear indication of $\mathrm{AOM}$ with $\delta^{13} \mathrm{C}_{\mathrm{DIC}}$ values as low as $-57 \%$. At two of the four sites drilled on the east-west transect (Sites U1326 and U1327), there is also evidence for a significant contribution of AOM to carbon cycling in the upper 20 mbsf (Fig. F3). In contrast, Site U1325 shows no indication of AOM. There is no correspondence, however, between the depth of the SMT, the relative contribution of AOM versus organic matter degradation, and the thickness of the GHSZ. This observation has been also reported in samples collected from the Indian Ocean (Kastner et al., in press) and illustrates the complexity of issues involving methane generation, transport, and consumption by AOM. Although methane availability is indeed a key factor controlling the distribution and concentration of gas hydrates, other issues, particularly the grain size of the host sediment, seem to play a determinant role in subsurface methane hydrology and resulting gas hydrate distribution and abundance (Torres et al., 2008).

In addition to characterizing DIC sources (organic matter degradation versus methane oxidation) and transport mechanisms (advection of deep fluids at the ridge summit), $\delta^{13} C_{D I C}$ in pore fluids is incorporated into authigenic carbonate phases, which constitute an integrated record of carbon cycling and fluid flow. Carbonate samples were collected during Expedition 311. A synthesis of $\delta^{13} \mathrm{C}_{\mathrm{DIC}}$ and authigenic carbonates would be used to provide a broad framework to unravel the history of gas hydrate formation and destabilization on the Cascadia margin (B. Teichert, pers. comm., 2007).

\section{References}

Claypool, G.E., Milkov, A.V., Lee, Y.-J., Torres, M.E., Borowski, W.S., and Tomaru, H., 2006. Microbial methane generation and gas transport in shallow sediments of an accretionary complex, southern Hydrate Ridge (ODP Leg 204), offshore Oregon, USA. In Tréhu, A.M., Bohrmann, G., Torres, M.E., and Colwell, F.S. (Eds.), Proc. ODP, Sci. Results, 204: College Station, TX (Ocean Drilling Program), 1-52. doi:10.2973/ odp.proc.sr.204.113.2006

Colwell, F.S., Boyd, S., Delwiche, M.E., Reed, D.W., Phelps, T.J., and Newby, D., 2008. Estimates of biogenic methane production rates in deep marine sediments at Hydrate Ridge, Cascadia margin. Appl. Environ. Microbiol., 74(11):3444-3452. doi:10.1128/AEM.02114-07

Kastner, M., Torres, M.E., Solomon, E., and Spivack, A., in press. Marine pore fluid profiles of dissolved sulfate: do they reflect in situ methane fluxes? Fire Ice.

Malinverno, A., Kastner, M., Torres, M.E., and Wortmann, U.G., 2008. Gas hydrate occurrence from pore water chlorinity and downhole logs in a transect across the northern Cascadia margin (Integrated Ocean Drilling Program Expedition 311). J. Geophys. Res., 113(B8):B08103. doi:10.1029/2008JB005702

Pohlman, J.W., Kaneko, M., Heuer, V., Plummer, R., Coffin, R.B., and the IODP Expedition 311 Scientific Party, 2006. Molecular and isotopic characterization of gases from IODP Expedition 311: source and gas hydrate related controls. Eos, Trans. Am. Geophys. Union, 87(52)(Suppl.):0S11E-06. (Abstract)

Torres, M.E., Kastner, M., Wortmann, U.G., Colwell, F., and Kim, J., 2007. Estimates of methane production rates based on $\delta^{13} \mathrm{C}$ of the residual DIC in pore fluids from the Cascadia margin. Eos, Trans. Am. Geophys. Union, 88(52)(Suppl.):GC14A-04. (Abstract)

Torres, M.E., Mix, A.C., and Rugh, W.D., 2005. Precise $\delta^{13} \mathrm{C}$ analysis of dissolved inorganic carbon in natural waters using automated headspace sampling and continuousflow mass spectrometry. Limnol. Oceanogr.: Methods, 3:349-60.

Torres, M.E., and Rugh, W.D., 2006. Data report: isotopic characterization of dissolved inorganic carbon in pore waters, Leg 204. In Tréhu, A.M., Bohrmann, G., Torres, M.E., and Colwell, F.S. (Eds.), Proc. ODP, Sci. Results, 204: College Station, TX (Ocean Drilling Program), 1-16. doi:10.2973/odp.proc.sr.204.117.2006

Torres, M.E., Tréhu, A.M., Cespedes, N., Kastner, M., Wortmann, U.G., Kim, J.-H., Long, P., Malinverno, A., Pohlman, J.W., Riedel, M., and Collett, T., 2008. Methane hydrate formation in turbidite sediments of northern Cascadia, IODP Expedition 311. Earth Planet. Sci. Lett., 271(1-4):170-180. doi:10.1016/j.epsl.2008.03.061

Tréhu, A.M., Torres, M.E., Bohrmann, G., and Colwell, F.S., 2006. Leg 204 synthesis: gas hydrate distribution and dynamics in the central Cascadia accretionary complex. In Tréhu, A.M., Bohrmann, G., Torres, M.E., and Colwell, F.S. (Eds.), Proc. ODP, Sci. Results, 204: College Sta- 
tion, TX (Ocean Drilling Program), 1-40. doi:10.2973/ odp.proc.sr.204.101.2006

Whiticar, M.J., Hovland, M., Kastner, M., and Sample, J.C., 1995. Organic geochemistry of gases, fluids, and hydrates at the Cascadia accretionary margin. In Carson, B., Westbrook, G.K., Musgrave, R.J., and Suess, E. (Eds.), Proc. ODP, Sci. Results, 146 (Pt. 1): College Station,
TX (Ocean Drilling Program), 385-397. doi:10.2973/ odp.proc.sr.146-1.247.1995

Initial receipt: 25 June 2008

Acceptance: 18 September 2008

Publication: 30 April 2009

MS 311-206 
Figure F1. A. Map of study area showing location of areas targeted during ODP Leg 204 and IODP Expedition 311. B. Multibeam bathymetry map along the transect across the accretionary prism showing location of drilled sites and multichannel seismic (MCS) Line 8. Cold vent Site U1328 is $\sim 2$ nmi southeast of the transect (courtesy of D. Kelley, J. Delaney, and D. Glickson, University of Washington; C. Barnes and C. Katnick, Neptune Canada, University of Victoria; funded by University of Washington and W. M. Keck Foundation). C. Bathymetry of area targeted during Leg 204 showing location of the summit (Site 1249) where massive gas hydrate occurs near the seafloor.

A

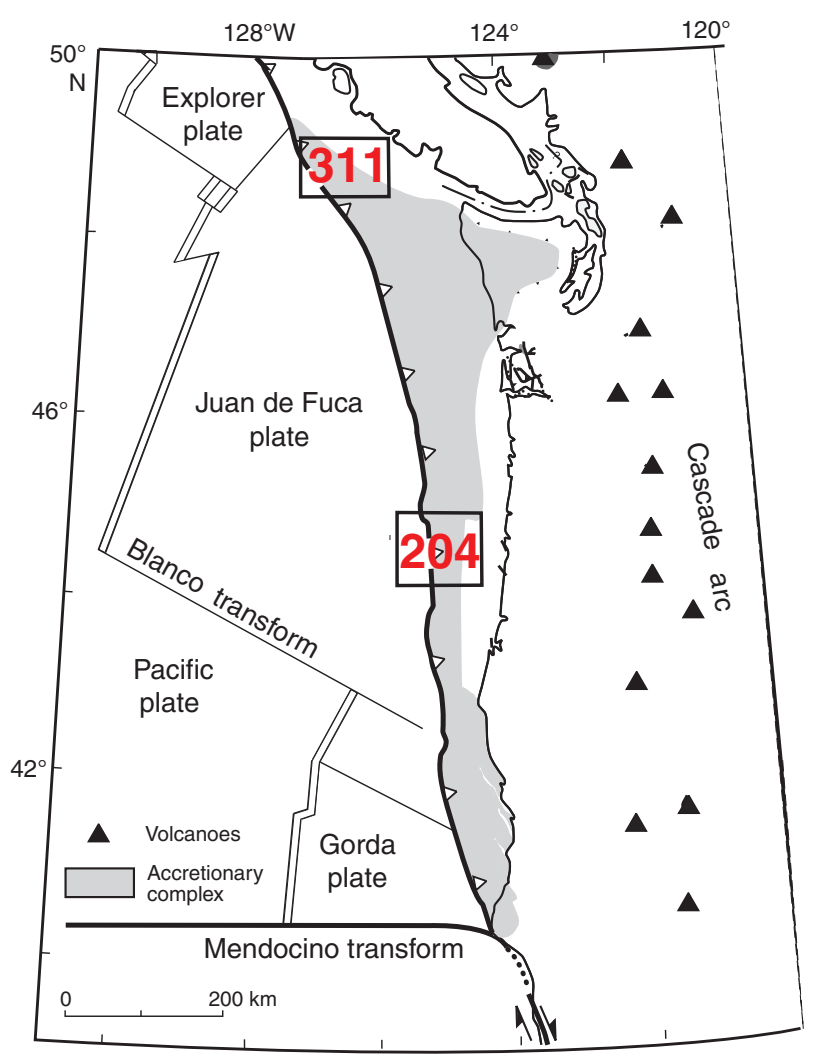

B

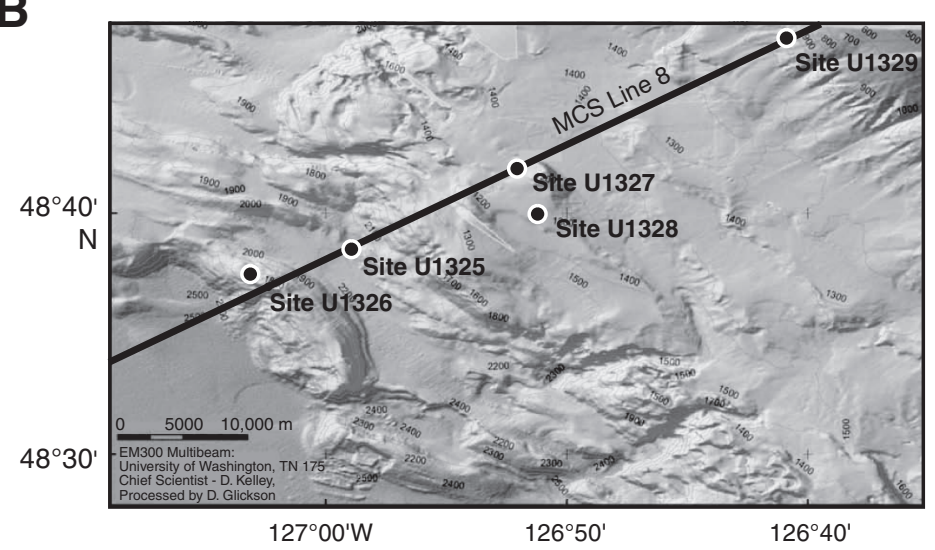

C

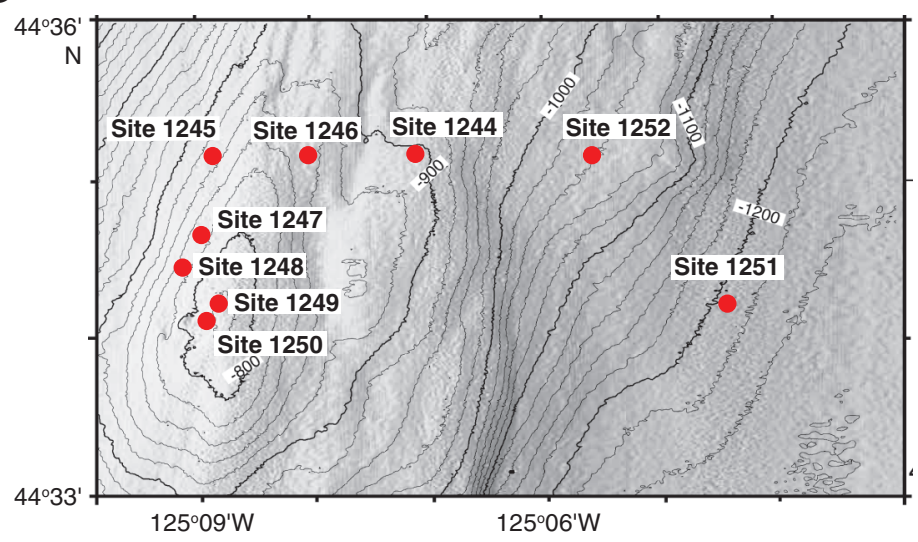


Figure F2. Downcore distributions of $\delta^{13} \mathrm{C}_{\mathrm{DIC}}$ along transect drilled during IODP Expedition 311 showing enrichment of isotope values of residual $\mathrm{CO}_{2}$, (A) Site U1325, (B) ODP Leg 204 Site 1245, (C) Site U1327, and (D) Site U1329. ODP Site 1245 is included for completeness (data from Torres and Rugh, 2006). E. Progressive enrichment in ${ }^{13} \mathrm{C}$ with distance from the deformation front reflecting preferential consumption of ${ }^{12} \mathrm{C}$ by methanogens, which leads to a progressively heavier residual pool. Site locations shown in Figure F1. DIC = dissolved inorganic carbon. PDB = Peedee belemnite.

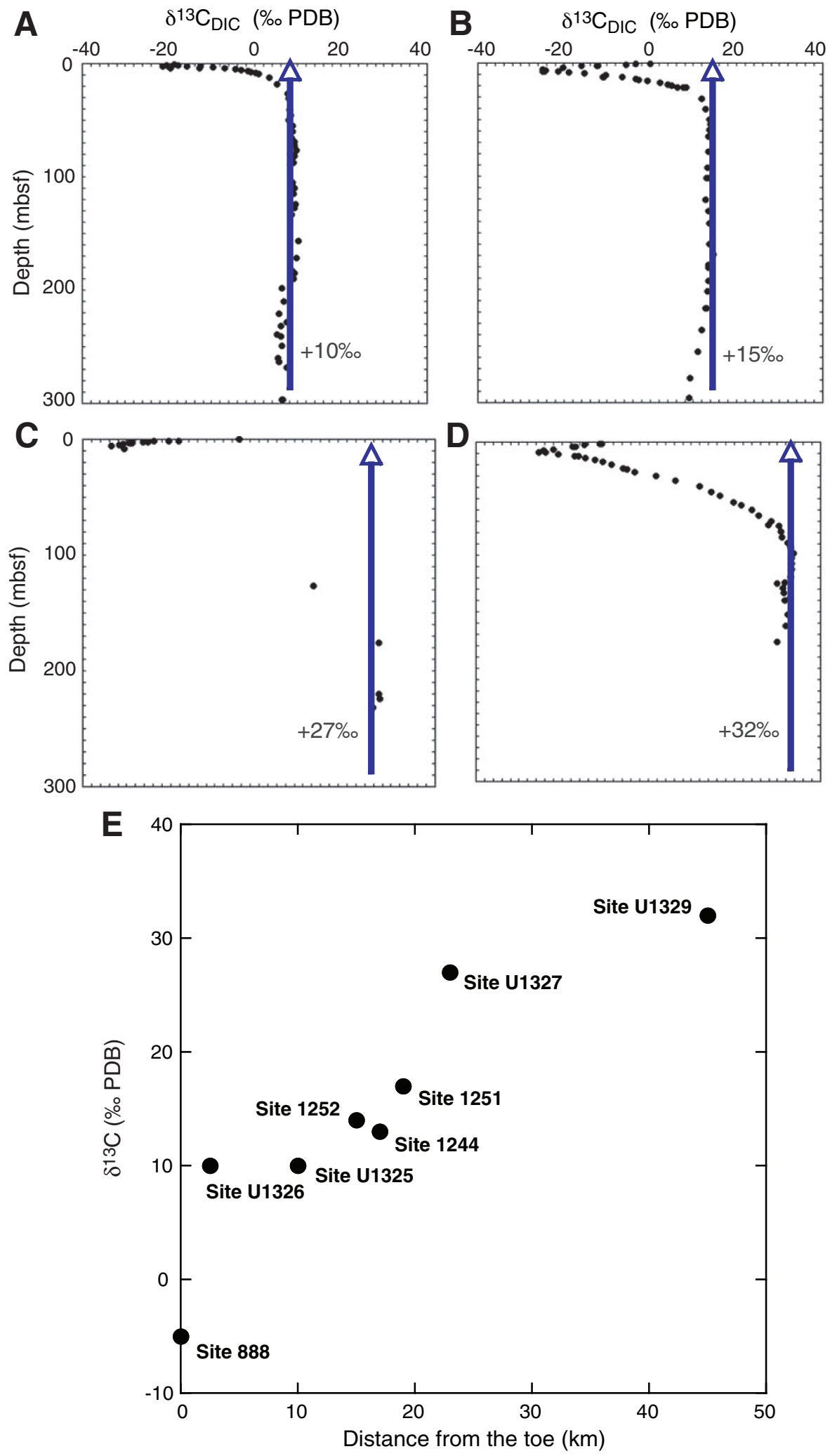


Figure F3. Downcore profiles of dissolved sulfate and $\delta^{13} \mathrm{C}_{\mathrm{DIC}}$ in upper $20 \mathrm{mbsf}$ of sediments recovered along the Expedition 311 transect, Sites (A) U1326, (B) U1325, (C) U1327, and (D) U1329. The lightest $\delta^{13} C_{D I C}$ values coincide with the sulfate depletion depth at the sulfate-methane transition (SMT) zone. Only at Sites U1326 and U1329 is there evidence for significant contribution of an AOM. E. Illustration of gas hydrate occurrence zone (GHOZ) (from Malinverno et al., 2008). There is no apparent relationship between the depth of the SMT, contribution of AOM, and thickness of gas hydrate occurrence zone. PDB = Peedee belemnite. GHSZ = gas hydrate stability zone.
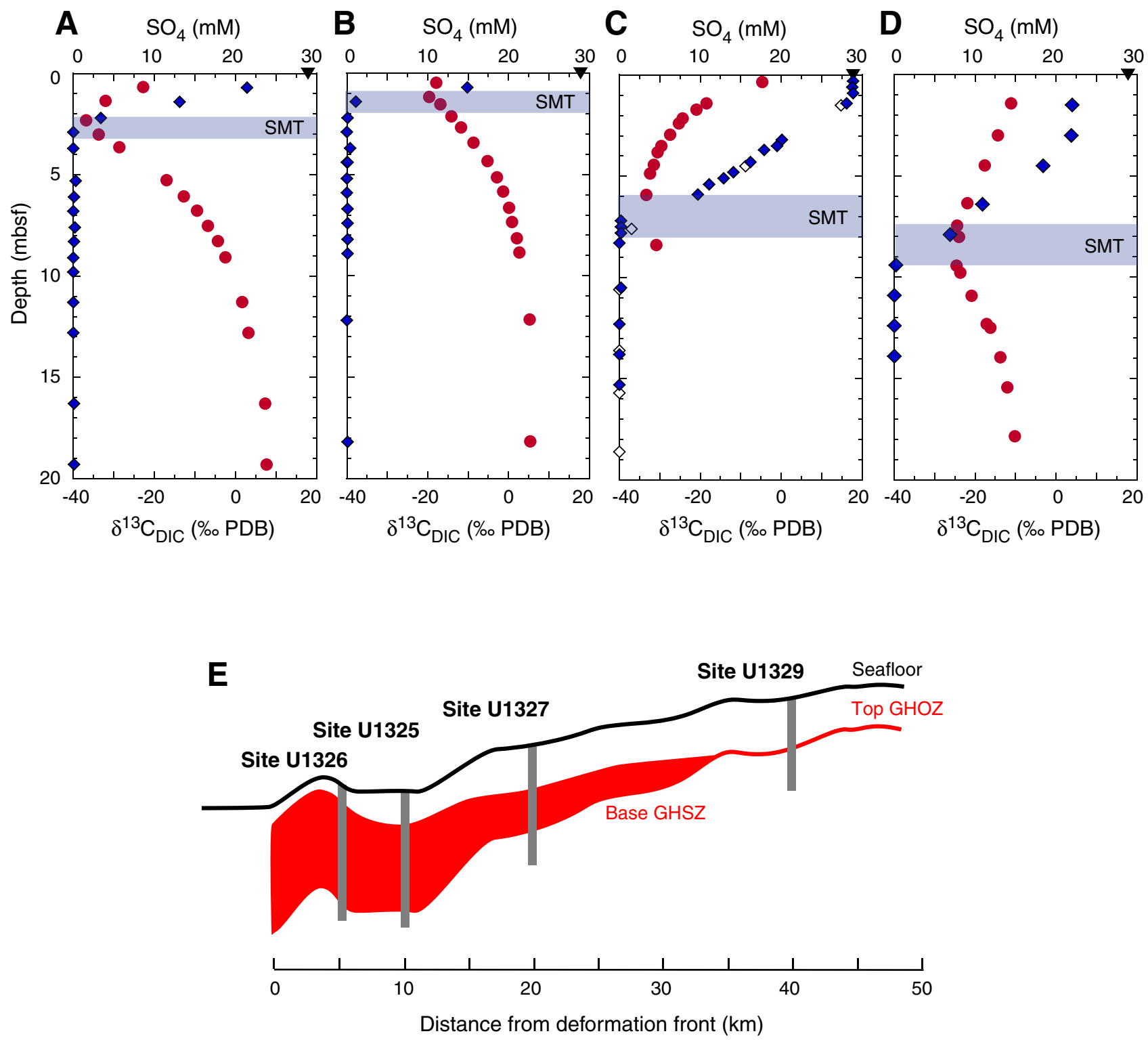
Table T1. Carbon isotopic composition of pore fluids, IODP Expedition 311. (See table note.)

\begin{tabular}{|c|c|c|}
\hline $\begin{array}{l}\text { Core, section, } \\
\text { interval }(\mathrm{cm})\end{array}$ & $\begin{array}{l}\text { Depth } \\
\text { (mbsf) }\end{array}$ & $\begin{array}{c}\delta^{13} C_{\mathrm{DIC}} \\
\text { (\%o PDB) }\end{array}$ \\
\hline \multicolumn{3}{|l|}{ 311-U1325B- } \\
\hline $12 X-4,68-93$ & 89.58 & 8.42 \\
\hline $14 \mathrm{X}-2,125-150$ & 105.05 & 8.85 \\
\hline $14 X-6,0-25$ & 109.63 & 9.27 \\
\hline $15 X-2,120-150$ & 114.40 & 8.73 \\
\hline $15 X-3,0-14$ & 114.70 & 9.00 \\
\hline $16 X-2,120-150$ & 124.00 & 9.44 \\
\hline $16 \mathrm{X}-4,25-35$ & 126.05 & 8.83 \\
\hline $16 X-6,120-150$ & 127.85 & 9.13 \\
\hline $18 X-2,126-156$ & 133.66 & 8.56 \\
\hline $20 X-5,120-150$ & 156.54 & 10.05 \\
\hline $23 X-1,120-150$ & 171.60 & 9.67 \\
\hline $24 \mathrm{X}-3,120-150$ & 182.97 & 8.83 \\
\hline $24 X-5,112-145$ & 185.39 & 9.26 \\
\hline \multicolumn{3}{|l|}{ 311-U1325C- } \\
\hline $1 X-1,120-150$ & 190.00 & 9.00 \\
\hline $2 X-1,0-43$ & 198.40 & 6.33 \\
\hline $4 X-3,0-79$ & 210.13 & 6.77 \\
\hline $6 X-3,88-112$ & 221.27 & 5.59 \\
\hline $7 X-2,0-50$ & 228.70 & 7.34 \\
\hline $7 X-4,69-79$ & 231.89 & 6.01 \\
\hline $8 X-2,62-85$ & 238.92 & 5.27 \\
\hline $8 X-4,0-50$ & 240.65 & 6.06 \\
\hline $9 X-2,100-150$ & 249.00 & 6.27 \\
\hline $11 X-2,105-150$ & 259.65 & 5.51 \\
\hline $11 X-5,0-45$ & 263.10 & 5.63 \\
\hline $12 X-3,0-45$ & 268.67 & 7.43 \\
\hline $15 X-3,0-134$ & 297.09 & 6.32 \\
\hline $15 X-3,0-134$ & 297.09 & 6.44 \\
\hline \multicolumn{3}{|l|}{ 311-U1325D- } \\
\hline $1 \mathrm{H}-1,140-150$ & 1.40 & -17.71 \\
\hline $1 \mathrm{H}-2,140-150$ & 2.90 & -21.39 \\
\hline $1 \mathrm{H}-3,130-140$ & 4.30 & -19.61 \\
\hline $1 \mathrm{H}-3,140-150$ & 4.40 & -12.83 \\
\hline \multicolumn{3}{|l|}{ 311-U1326C- } \\
\hline $1 \mathrm{H}-1,65-80$ & 0.65 & -23.05 \\
\hline $1 \mathrm{H}-1,135-150$ & 1.35 & -32.27 \\
\hline $1 \mathrm{H}-2,65-80$ & 2.15 & -36.93 \\
\hline $1 \mathrm{H}-2,135-150$ & 2.85 & -33.86 \\
\hline $1 \mathrm{H}-3,60-72$ & 3.60 & -28.87 \\
\hline $2 \mathrm{H}-1,135-150$ & 5.25 & -17.88 \\
\hline $2 \mathrm{H}-2,65-80$ & 6.05 & -13.67 \\
\hline $2 \mathrm{H}-2,135-150$ & 6.75 & -10.40 \\
\hline $2 \mathrm{H}-3,60-75$ & 7.50 & -7.73 \\
\hline $2 \mathrm{H}-3,135-150$ & 8.25 & -5.27 \\
\hline $2 \mathrm{H}-4,65-80$ & 9.05 & -3.42 \\
\hline $2 \mathrm{H}-5,135-150$ & 11.25 & 0.72 \\
\hline $2 \mathrm{H}-6,135-150$ & 12.75 & 3.07 \\
\hline $3 \mathrm{H}-2,135-150$ & 16.25 & 6.35 \\
\hline $3 \mathrm{H}-4,135-150$ & 19.25 & 6.73 \\
\hline $4 \mathrm{H}-2,130-150$ & 25.70 & 6.18 \\
\hline $6 X-2,125-150$ & 42.75 & 3.16 \\
\hline $7 X-1,93-133$ & 50.63 & -0.95 \\
\hline $7 X-3,74-101$ & 53.27 & -1.85 \\
\hline $9 X-2,0-25$ & 70.60 & -4.00 \\
\hline $9 X-3,66-91$ & 72.76 & -4.28 \\
\hline $10 X-2,0-30$ & 80.20 & -2.49 \\
\hline
\end{tabular}

\begin{tabular}{|c|c|c|}
\hline $\begin{array}{l}\text { Core, section, } \\
\text { interval }(\mathrm{cm})\end{array}$ & $\begin{array}{l}\text { Depth } \\
\text { (mbsf) }\end{array}$ & $\begin{array}{c}\delta^{13} C_{D I C} \\
(\% o \text { PDB) }\end{array}$ \\
\hline \multicolumn{3}{|l|}{ 311-U1326D- } \\
\hline $2 X-2,125-150$ & 91.15 & 2.93 \\
\hline $2 X-5,104-144$ & 95.44 & 2.18 \\
\hline $3 X-4,61-90$ & 103.21 & 3.15 \\
\hline $3 X-4,90-119$ & 103.50 & 6.20 \\
\hline $4 X-3,40-106$ & 111.10 & 6.42 \\
\hline $4 X-5,126-146$ & 114.37 & 5.15 \\
\hline $5 X-4,115-150$ & 122.69 & 7.29 \\
\hline $6 \mathrm{X}-4,90-132$ & 132.03 & 8.47 \\
\hline $8 X-2,36-86$ & 148.16 & 11.87 \\
\hline $9 X-1,84-134$ & 156.74 & 11.85 \\
\hline $9 X-4,35-48$ & 158.46 & 9.62 \\
\hline $10 X-2,97-142$ & 168.07 & 10.75 \\
\hline $10 X-6,0-66$ & 172.02 & 8.10 \\
\hline $11 \mathrm{X}-1,38-49$ & 175.58 & 6.32 \\
\hline $11 X-4,100-150$ & 179.69 & 8.49 \\
\hline $12 X-1,75-125$ & 185.55 & 5.62 \\
\hline $12 X-3,100-150$ & 188.55 & 5.83 \\
\hline $12 X-3,100-150$ & 188.55 & 6.47 \\
\hline $13 X-4,60-112$ & 198.60 & 4.51 \\
\hline $14 X-3,58-73$ & 206.85 & 3.05 \\
\hline $14 X-5,0-50$ & 208.50 & 5.26 \\
\hline $15 X-5,50-100$ & 219.86 & 3.57 \\
\hline $16 \times-3,0-50$ & 226.30 & 1.33 \\
\hline $16 \times-5,0-52$ & 228.90 & 1.20 \\
\hline $17 X-3,0-100$ & 235.90 & 3.94 \\
\hline $18 X-3,0-90$ & 244.61 & 5.12 \\
\hline $19 X-2,0-83$ & 253.61 & 5.78 \\
\hline $20 X-4,50-150$ & 265.54 & 5.22 \\
\hline $20 X-6,0-100$ & 268.04 & 2.30 \\
\hline \multicolumn{3}{|l|}{ 311-U1327C- } \\
\hline $1 \mathrm{H}-1,140-150$ & 1.50 & -18.09 \\
\hline $1 \mathrm{H}-3,140-150$ & 4.50 & -30.75 \\
\hline $16 \mathrm{X}-2,120-150$ & 126.70 & 12.31 \\
\hline $21 X-4,81-150$ & 175.70 & 27.23 \\
\hline $27 X-1,108-138$ & 219.70 & 27.16 \\
\hline $27 X-4,114-144$ & 224.00 & 27.38 \\
\hline $28 X-3,96-125$ & 232.10 & 25.83 \\
\hline \multicolumn{3}{|l|}{ 311-U1327D- } \\
\hline $1 \mathrm{H}-1,25-40$ & 0.30 & -4.57 \\
\hline $1 \mathrm{H}-1,135-150$ & 1.40 & -18.29 \\
\hline $1 \mathrm{H}-2,25-50$ & 1.80 & -20.36 \\
\hline $1 \mathrm{H}-2,55-70$ & 2.10 & -23.78 \\
\hline $1 \mathrm{H}-2,80-95$ & 2.40 & -25.11 \\
\hline $1 \mathrm{H}-2,135-150$ & 2.90 & -26.37 \\
\hline $1 \mathrm{H}-3,40-55$ & 3.50 & -28.75 \\
\hline $1 \mathrm{H}-3,65-80$ & 3.70 & -29.46 \\
\hline $1 \mathrm{H}-4,25-40$ & 4.80 & -31.57 \\
\hline $1 \mathrm{H}-4,135-150$ & 5.90 & -33.47 \\
\hline $2 \mathrm{H}-1,135-150$ & 8.30 & -30.45 \\
\hline \multicolumn{3}{|l|}{ 311-U1328B- } \\
\hline $1 \mathrm{H}-1,40-50$ & 0.50 & -3.86 \\
\hline $1 \mathrm{H}-1,140-150$ & 1.50 & -16.93 \\
\hline $1 \mathrm{H}-2,70-80$ & 2.30 & -56.75 \\
\hline $1 \mathrm{H}-2,140-150$ & 3.00 & -48.32 \\
\hline $2 \mathrm{H}-1,80-100$ & 5.40 & 8.30 \\
\hline $4 \mathrm{P}-1,36-46$ & 14.90 & -3.02 \\
\hline
\end{tabular}

\begin{tabular}{|c|c|c|}
\hline $\begin{array}{l}\text { Core, section, } \\
\text { interval }(\mathrm{cm})\end{array}$ & $\begin{array}{l}\text { Depth } \\
\text { (mbsf) }\end{array}$ & $\begin{array}{c}\delta^{13} C_{D I C} \\
(\% o \text { PDB })\end{array}$ \\
\hline \multicolumn{3}{|l|}{ 311-U1328D- } \\
\hline $1 X-4,135-150$ & 5.90 & -51.14 \\
\hline $1 X-5,135-150$ & 7.40 & -46.86 \\
\hline \multicolumn{3}{|l|}{ 311-U1329C- } \\
\hline $1 \mathrm{H}-1,140-150$ & 1.40 & -10.83 \\
\hline $1 \mathrm{H}-3,140-150$ & 4.40 & -16.95 \\
\hline $1 \mathrm{H}-5,140-150$ & 7.40 & -24.36 \\
\hline $2 \mathrm{H}-1,140-150$ & 9.50 & -23.78 \\
\hline $2 \mathrm{H}-3,140-150$ & 12.50 & -16.26 \\
\hline $2 \mathrm{H}-5,140-150$ & 15.50 & -12.24 \\
\hline $2 \mathrm{H}-7,74-84$ & 17.84 & -10.51 \\
\hline $3 \mathrm{H}-2,135-150$ & 20.45 & -8.54 \\
\hline $3 \mathrm{H}-4,135-150$ & 23.45 & -5.92 \\
\hline $3 \mathrm{H}-6,135-150$ & 26.45 & -3.09 \\
\hline $4 \mathrm{H}-2,120-150$ & 29.80 & 1.73 \\
\hline $4 \mathrm{H}-5,120-150$ & 4.30 & 21 \\
\hline $5 \mathrm{H}-2,130-150$ & 39.40 & 12.00 \\
\hline $5 \mathrm{H}-5,130-150$ & 43.90 & 14.62 \\
\hline $6 \mathrm{H}-1,135-150$ & 47.45 & 16.68 \\
\hline $6 \mathrm{H}-5,135-150$ & 53.45 & 19.77 \\
\hline $7 P-1,25-50$ & 5 & 21.64 \\
\hline $8 \mathrm{H}-2,135-150$ & 60.45 & 23.99 \\
\hline $8 \mathrm{H}-5,135$ & 64.95 & 25.60 \\
\hline $9 \mathrm{H}-2,135-150$ & 69.95 & 28.62 \\
\hline $9 \mathrm{H}-5,130-150$ & 74.40 & 30.42 \\
\hline $10 \mathrm{H}-2,130-150$ & 79.40 & 30.88 \\
\hline $10 \mathrm{H}-5,130-150$ & 83.90 & 31.03 \\
\hline $11 \mathrm{H}-2,130-150$ & 88.90 & 32.42 \\
\hline $11 \mathrm{H}-5,13$ & 93.40 & 33.10 \\
\hline $12 \mathrm{H}-2,120-150$ & 98.28 & 33.63 \\
\hline $12 \mathrm{H}-5,130-150$ & 102.88 & 33.25 \\
\hline $13 \mathrm{H}-2,130-150$ & 07.90 & 33.28 \\
\hline $13 \mathrm{H}-5,13$ & 112.40 & 33.24 \\
\hline $15 \mathrm{H}-2,130-150$ & 119.40 & 33.01 \\
\hline $15 \mathrm{H}-5,130-150$ & 123.90 & 31.81 \\
\hline $16 \mathrm{H}-2,130-150$ & 128.90 & 31.31 \\
\hline $16 \mathrm{H}-5,13$ & 133.40 & 31.45 \\
\hline $17 \mathrm{H}-2,1$ & 138 & 32.76 \\
\hline $17 \mathrm{H}-3,130-150$ & 139.85 & 31.74 \\
\hline $19 X-2,120-150$ & 152.60 & 32.47 \\
\hline $20 \mathrm{X}-2,120-150$ & 162.30 & 31.95 \\
\hline $21 X-6,0-30$ & 176.30 & 29.86 \\
\hline \multicolumn{3}{|l|}{ 311-U1329E- } \\
\hline 141 & 1.40 & -11.34 \\
\hline $1 \mathrm{H}-2,140-150$ & 2.90 & -14.76 \\
\hline $1 \mathrm{H}-3,140-150$ & 4.40 & -17.57 \\
\hline $2 \mathrm{H}-1,135-150$ & 6.35 & -22.05 \\
\hline $2 \mathrm{H}-2,135-150$ & 7.85 & -24.26 \\
\hline $2 \mathrm{H}-3,135-150$ & 9.35 & -25.29 \\
\hline $2 \mathrm{H}-4,135-150$ & 10.85 & -20.81 \\
\hline $2 \mathrm{H}-5,135-150$ & 12.35 & -17.07 \\
\hline $2 \mathrm{H}-6,135-150$ & 13.85 & -14.60 \\
\hline $3 \mathrm{H}-7,63-78$ & 24.13 & -4.91 \\
\hline & & 27.89 \\
\hline 10P-1, 18-59 & 125.18 & 29.94 \\
\hline
\end{tabular}

Note: $\mathrm{PDB}=$ Peedee belemnite. 